\title{
Indonesian Democracy: What to Do with Political Violence?
}

\author{
Elyzabeth B. Nasution \\ Universitas Pelita Harapan (UPH) \\ Indonesia \\ elyzabeth.nasution@uph.edu
}

\begin{abstract}
Perhaps the most common things to witness in Indonesian style of democracy are religious conflict and violent action that follows the aftermath of the conflict. Across the country from burning churches in Aceh province to Poso riots, Indonesia is flooded with rigorous conflict and violence. Some might say that these are the consequence of the old government of New Order; other might claim that this series of struggles are part of our democracy learning process. Whatever the explanation, it is clear that democracy is questionable; is it truly the best form of government?

The paper proposes that every form of government has its own merits; however, democracy appears to be the most beneficial although it comes with a price. Indonesia is indeed democratic, though the dominating top-down system seems to be still in existence. The paper depicts collective violence in Indonesia since the downfall of the New Order up until the Reformation era. It then explains the causes of collective violence and finally provides realistic suggestions and recommendations for us - the government and the people - to accommodate these conflict and violence. The paper suggests that political violence and religiously motivated attacks are treatable - if not avoidable - and peace education is imperative to accommodate them.
\end{abstract}

Keywords: democracy, collective violence, political violence, peace education.

\section{INTRODUCTION}

From a social perspective, Indonesia's transition to peaceful democracy has been particularly troubled. Religiously motivated attacks - done by individuals and/or groups towards other individuals and/or groups - have been the highlight of Indonesian democracy. Unfortunately, some parts of Indonesia, including the authorities, do no longer perceive this as unacceptable, rather expected. The problem is clear; for some parties, violence is accepted as an unavoidable consequence of being a democratic country. Violence for most of the time is even considered as necessary; as an effective instrument achieving (political) interests.

This paper highlights the pattern of what Varshney, Tadjoeddin and Panggabean call as collective violence In Indonesia from early days of democracy (right after the fall of New Order), the cause(s), and offers several realistic ideas regarding the issue. It is imperative to have clear characteristics of political violence occurring in Indonesia and even more paramount to identify the perpetrators before providing solutions. Democracy does come with substantial price, however, like Almond, Powell, Dalton, and Strøm emphasize, democracy is a political system in which citizens enjoy a number of basic civil and political rights, and in which their most important political leaders are elected in free and fair elections and accountable under a rule of law. Democracy provides an opportunity for people to live with their 'enemies'because only democracy that makes tension and paradox - which come originally from freedom possible in society. There is still hope for peaceful democracy in Indonesia.

\section{COLLECTIVE VIOLENCE IN INDONESIA}

\section{A. The Fact}

Many scholars have agreed that (political) violence in Indonesia is highly related to the existence of the New Order regime, even until its downfall. Hence the work of Varshney, Tadjoeddin, and Panggabean is the first the author relies on. It is a result of approximately 10,000 hours of work done by a team of fourteen researchers, most of them based in provincial capitals. The result is beyond shocking: there were 3,600 incidents of violence, of which more than a quarter - a little over 1,000 incidents - resulted in over 10,700 deaths during the period of 1990-2003. It should be specified that Varshney, Tadjoeddin, and Panggabean did not cover all forms of violence, only collective violence. They define it as violence perpetrated by a group on another group (as in riots), by a group on an individual (as in lynching), by an individual on a group (as in terrorist acts), by the state on a group, or by a group on organs or agencies of the state.

Given the fact that New Order did not allow press freedom in more than three decades of existence, Varshney, Tadjoeddin, and Panggabean decided to dig reliable, unambiguous information from the provincial newspaper. They concentrated on fourteen provinces: Riau, Jakarta, Central Java, West Java, East Java, Banten, Central Kalimantan, West Kalimantan, South Sulawesi, Central Sulawesi, East Nusa Tenggara, West Nusa Tenggara, Maluku, and North Maluku. Why these fourteen provinces though? The fourteen provinces accounted for 96.4 percent of all deaths, and according to the 2000 census, 72.4 percent of Indonesian population lived in those provinces. Moreover, there are four categories of collective violence: (1) ethno-communal (interethnic, interreligious, and intrareligious); (2) state versus community (attacks by government machinery on civilians and vice versa); (3) economic (conflicts over land, industrial relations, and natural resources); and (4) other (lynching, inter-village 
brawls, etc.). Simply put, the following tables depict the results more clearly.

Table 1 Collective Violence in Indonesia, 1990-2003: Provincial Distribution

\begin{tabular}{lrcrc} 
& Deaths & Percentage & Incidents & Percentage \\
\cline { 2 - 5 } North Maluku & 2,794 & 25.0 & 72 & 1.7 \\
Maluku & 2,046 & 18.3 & 332 & 7.8 \\
West Kalimantan & 1,515 & 13.6 & 78 & 1.8 \\
Jakarta & 1,322 & 11.8 & 178 & 4.2 \\
Central Kalimantan & 1,284 & 11.5 & 62 & 1.5 \\
Central Sulawesi & 669 & 6.0 & 101 & 2.4 \\
West Java & 256 & 2.3 & 871 & 20.4 \\
East Java & 254 & 2.3 & 655 & 15.3 \\
Central Java & 165 & 1.5 & 506 & 11.9 \\
South Sulawesi & 118 & 1.1 & 223 & 5.2 \\
West Nusatenggara & 109 & 1.0 & 198 & 4.6 \\
Riau & 100 & 0.9 & 165 & 3.9 \\
East Nusatenggara & 89 & 0.8 & 55 & 1.3 \\
Banten & 37 & 0.3 & 112 & 2.6 \\
Total & 10,758 & 96.4 & 3,608 & 84.5 \\
\hline
\end{tabular}

Table 2 Collective Violence in Indonesia, 1990-2003: by Category

\begin{tabular}{lrccc}
\hline Category & Deaths & Percentage & Incidents & Percentage \\
\hline Ethnocommunal & 9,612 & 89.3 & 599 & 16.6 \\
State-community & 105 & 1.0 & 423 & 11.7 \\
Economic & 78 & 0.7 & 444 & 12.3 \\
Other & 963 & 9.0 & 2,142 & 59.4 \\
Total (14 provinces) & 10,758 & 100.0 & 3,608 & 100.0 \\
\hline
\end{tabular}

Moving on the slightly more updated and specified facts, let's talk about recent violence in Indonesia with identified perpetrators. During the presidency of Susilo Bambang Yudhoyono (2004-2010) religiously motivated attacks by Islamic vigilante groups such as the Islamic Defenders Front (Front Pembela Islam, FPI), the Islamic Community Forum (Forum Umat Islam, FUI), the Movement against Illegal Sects and Non-believers (Gerakan Anti Permurtadan dan Aliran Sesat, GAPAS), and the Indonesia Mujahidin Council (Majelis Mujahidin Indonesia, MMI) grew drastically. Over 30 attacks against Christian churches took place through 2010, 12 more than during the whole of 2009. Attacks on Ahmadiyah, an unorthodox Muslim sect, also spiked. One prominent incident occurred in Bekasi, West Java, where several hundred members of FUI overran an open-air worship service of the Batak Christian Protestant Church (Huria Kristen Batak Protestant, HKBP) on churchowned land, injuring 20 people, mostly women. In another incident, violence erupted between local residents, police, and various vigilante groups after the local district chief of Kuningan Regency in West Java forced the closure of eight Ahmadiyah mosques.

More unsettling facts are provided by Sydney Jones whose research includes Gerakan Reformis Islam (GARIS), an undemocratic civil society that was created in 1998. GARIS is responsible for vandalism (more specifically the burning of worship places) and violent attacks on Ahmadiyah in Cianjur in 2005. According to Chep Hernawan, leader of GARIS, Jaringan Islam Liberal (liberal Islam network), HKBP, and atheist-communist are the biggest threats to West Java.

B. The Cause
Some clarifications and explanations to these findings are mandatory. The most striking difference between the New Order and the post-Suharto period is not that one was peaceful and the other has had a lot of violence. Rather, the New Order often used state-perpetrated violence to bring order, whereas clashes between social groups have been more common since 1998. The downfall of New Order has provided certain individuals and groups with opportunities to take the matter into their own hands. Perhaps an analogy of a dog that has been long kept in a kennel and finally had a chance to be free is ideal.

Colombijn and Lindblad even underline the present violence is not simply, or not only, the legacy of the New Order. The New Order was an instance of a longer historical tradition of violence. Finally, violence did not erupt after 1998 because the New Order's disciplinary mechanisms collapsed; rather, violence was one of the fundamental pillars on which the New Order rested. In the end, the problem of legitimacy led to the collapse of the New Order and also left a violent trail. The New Order, in short, is itself the cause of the violence, both during its life span and after its death.

One thing that should be underlined is that the characteristic of violence that occurred right after the end of the New Era was different from the violence that took place and is still taking place after Indonesia's first direct election in 2004. The first was more political whereas the later might be more social. FPI for instance, as leading vigilante group, has explicitly clarified this. In 2005, FPI stated that "... nasionalisme dan gagasan bela bangsa sudah ketinggalan zaman; sekarang, pada era reformasi, kegiatan anti kemaksiatan atas nama Islam jauh lebih seksi." FPI has been known to radically eradicate anything that relates to what it perceives as immoral, non-believer (sesat), and sinful (maksiat).

Social and political scholars have long thought that current 'trend' of religious violence in Indonesian democracy, including the rising theme on studies on Islamic radicalism movement, is highly related to the Global War on Terror by the United States of America, following the 9/11 attacks. Simultaneously terror attacks on behalf of Islam after Reformation in Indonesia started to bring the issue of Islam radicalism to the surface.

At the same time state is seen weak - if not accommodative to those vigilante groups. In many occasions, the authorities were even leaning towards the violence perpetrators. Twice in Jogjakarta (2012 and 2014), this premise has been proven. In 2012, the mayor of Jogjakarta stopped Jalsah study (pengajian) due to an anarchical demonstration that demanded the study be ended. In 2014, Front Jihad Islam (FJ) attacked a Passover ritual in Gunung Kidul. The local police decided not to hold anyone responsible - let alone arrested - due to lack of evidence even though casualties were more than significant. 


\section{WHAT TO DO?}

The matter calls for two levels of actions. From the top, there should be clear and assertive regulations that state official, both central and local, must not have any affiliations and associations with the groups that have allegedly perpetrated religiously motivated attacks and violence. The fact that several state officials were even involved in events held by those groups is alarming. Additionally, law enforcement should cover one more aspect into criminality, and that is zero tolerance for violence. No matter whom the perpetrator is, how insignificant the violence might seem, it is wrong to take matters into one's hands. Given the fact that out of fourteen provinces where collective violence occurred most frequently, all Java provinces are included, we could argue that vigilante groups do aim provinces with suffice governmental instrument and in which Indonesian population is concentrated.

From the bottom, and this one requires deeper commitment and consistency, Indonesian people should be taught of peaceful education. Peaceful education, in my term, entails constant learning of pluralism and tolerance. Being a pluralist does not necessarily mean that we accept differences; we simply acknowledge its existence. The problem in Indonesia is that nowadays people do harden their identity (such identity could be religion, ethnicity, or race) causing them to be exclusive and intolerant to differences. The old Indonesian saying Tak kenal maka tak sayang is indeed true. People need to know each other first, not judge each other.

To do so, we may start from school. The Nee Order's legacy for students to only learn their religion is obscene. Students should be given the opportunity to learn other religions as well. The school also could offer them to learn about the comparison of religions (perbandingan agama), academically speaking, or ethics to keep them on the right track. Students whose religions are not nationally acknowledged in Indonesia could benefit from this method as well.

From there, people finally can have effective interfaith dialogue. An effective interfaith dialogue is not a dialogue where people would simply gather and listen to other sharing their beliefs. In it, people will contribute. For example, the dialogue is held before Ramadan, the holy month for Muslims. In that dialogue, the non-Muslims will be asked for their participation keeping the mosques safe during breakfasting or waking people up in the dawn for sahur. When Christmas season comes, the Muslims contribute by decorating giant Christmas tree or distributing foods for the hungry. The contribution is the keyword. Of course, it should all start with making sure that everyone involved is on the same page. That being said, theoretical explanation of Islam and other religion is indeed needed, but it stops at knowing and acknowledging; there is no need to politely or impolitely enforce a religion towards others. Effective interfaith dialogue emphasizes on ideas changing, contribution, and appreciation, not on dogmatizing and attacking. Actions from the bottom have always been challenging. They require a great amount of time and energy before being cultivated, however, the result is often sustainable since it is built on solid, firm ground. Indonesian democracy might seem uncivil and violent at the moment, however, as it is defined - government by people democracy needs people to be politically operational and Indonesian people have not given up hope.

\section{References}

[1] A. Varshney, M.Z. Tadjoeddin, and R. Panggabean, 'Creating Datasets in Information-Poor Environments: Patters of Collective Violence in Indonesia, 1990-2003', Journal of East Asian Studies, vol 8, no. 3, SeptemberDecember 2008, pp. 361-394.

[2] E. Kimura, 'Indonesia in 2010 A Leading Democracy Disappoints on Reform', Asian Survey, vol. 51, no 1, January/February 2011, pp. 186-195.

[3] E.J. Sarapung, 'Tantangan Berdemokrasi di Indonesia: Mempertanyakan Komitmen Pemerintah Menghadapi Kelompok Masyarakat Sipil Intoleran', in S. Jones (ed.), Sisi Gelap Demokrasi: Kekerasan Masyarakat Madani di Indonesia, PUSAD Paramadina, Jakarta, 2015.

[4] F. Colombijn and J.T. Lindblad, Roots of Violence in Indonesia: Contemporary Violence in Historical Perspective, KITLV Press, Leiden, 2002.

[5] G.A. Almond, G.B.J. Powell Jr., R.J. Dalton, and K. Strøm, Comparative Politics Today: A World View, Pearson, London, 2006.

[6] J. Bertrand, Nationalism and Ethnic Conflict in Indonesia, Cambridge University Press, Cambridge, 2004.

[7] M.N. Azca, 'Yang Madani Namun Intoleran? Trayektori dan Variasi Gerakan Islam Radikal di Indonesia', in S. Jones (ed.), Sisi Gelap Demokrasi: Kekerasan Masyarakat Madani di Indonesia, PUSAD Paramadina, Jakarta, 2015.

[8] S. Jones, Sisi Gelap Demokrasi: Kekerasan Masyarakat Madani di Indonesia, PUSAD Paramadina, Jakarta, 2015. 